\title{
REQUESTS BY THE GOVERNMENT FOR MODIFICATION OF CONSENT DECREES
}

Parties to litigation may effect a binding settlement of their dispute without a full trial by negotiating a consent decree in private and then presenting it to the court for approval. When entered by the court, the decree has the same force as a decree entered after litigation. ${ }^{1}$ The use of consent decrees presents significant advantages to all the parties. For example, in the antitrust field the Government has used consent decrees extensively in order to enforce the antitrust laws quickly and economically. ${ }^{2}$ The defendant has a similar interest in avoiding time-consuming and costly litigation; also he may obtain a more lenient decree by not forcing a trial. ${ }^{3}$ And in the antitrust field there is the added advantage that consent decrees may not be used as prima facie evidence of the defendant's guilt in subsequent treble damage suits. ${ }^{*}$

The terms of consent decrees often establish continuing restrictions upon the future actions of the parties. Occasionally, however, a party may become dissatisfied with the operation of the decree and will request the court to modify or vacate. In the landmark decision of United States v. Swift is Co., ${ }^{5}$ the Supreme Court held that such modification, when contested, should be allowed only in rare instances.

The Swift case involved a consent decree which had dissolved an alleged monopoly in the food industry. In order to prevent further violations of the antitrust laws, the decree had placed significant re-

1. Anttrkust Subcomar., House Comm. on the Judiciary, 86ti Cong., lst Sess, Report on the Consent Decree Program of the Departament of Justice 2-3 (Comm. Print 1959) [hereinafter cited as REPORT].

2. Between 1935 and 1958 more than seventy per cent of all civil antitrust suits initiated by the Justice Department were settled by consent decree. Mintos S. GoLdnesc, The Consent Decree: Its Formulation and Use 6 (Occasional Paper No. 8, Bureau of Business and Economic Research, Michigan State University 1962); REPORT ix. For the advantages of antitrust consent decrees to both the Government and private defendants, see GoldeErc, supra at 3.

3. In negotiating antitrust consent decrees the Justice Department often seeks to include provisions which it feels are in the public interest but which "go beyond what the law: requires." Oppenheim, Federal Antitrust Legislation: Guideposts to a Revised National Antitrust Policy, 50 Mrch. L. REv. 1139, 1232 (1952). But the Department has also consented to decrees which included less than the law requires. As a result, the Department has been severely criticized. REPORT 290-99. See generally GoLDEERG, op. cit. supra note 2, chs. IV, V.

4. Clayton Act $\S 5(a), 38$ Stat. 731 (1914), as amended, 15 U.S.C. $\S 16(a)$ (1964).

5. 286 U.S. 106 (1932). 
strictions upon the defendants' future activities. Twelve years later ${ }^{0}$ the defendants sought modification, arguing that conditions had so changed that the restrictions the decree imposed were "useless and oppressive."' The district court allowed modification, but the Supreme Court reversed. The Court acknowledged the district court's power to modify a continuing injunction ${ }^{8}$ but severely limited the circumstances under which that power should be exercised. According to Mr. Justice Cardozo: "nothing less than a clear showing of grievous wrong evoked by new and unforeseen conditions should lead us to change what was decreed after years of litigation with the consent of all concerned."

Under the current interpretation of the rule of Stvift, two requirements must be met. First, a defendant must demonstrate a change in conditions. ${ }^{10}$ This change-which may be one of fact or law ${ }^{11}$-must be such that "dangers, once substantial, have become attenuated to a shadow"12 so that the original need for the decree no longer exists. ${ }^{10}$ Second, a defendant must show that he faces undue hardship should the decree remain in force. ${ }^{14}$ This hardship must be "evoked by new and unforeseen conditions"15 and must be distinguished from hardships which have been imposed in the public interest by the terms of the decree. The latter hardships, having been accepted knowingly, will not justify subsequent modification. ${ }^{10}$

6. During this time the defendants unsuccessfully challenged the validity of the consent decree as a jural device. Swift \& Co. v. United States, 276 U.S. 811 (1928).

7. United States v. Swift \& Co., 286 U.S. at 113.

8. Id, at 114 .

9. Id. at 119. FED. R. Crv. P. 60(b)(5) permits a court to "relieve a party or his legal representative" from a final judgment if it "is no longer equitable that the judgment should have prospective application." This rule is regarded as establishing a procedural innovation only; it enacted existing substantive law. United States v. Swift \& Co., 189 F. Supp. 885, 905 (N.D. Ill. 1960), aff'd per curiam, 367 U.S. 909 (1961) (denying a second attempt by Swift to obtain modification of the original consent decree). See 7 MoORE, Feneral Practice I 60.26(4) (2d ed. 1953).

10. United States v. Swift \& Co., 189 F. Supp. 885, 906, 912 (N.D. IIl. 1960).

11. Systems Fed'n No. 91, Ry. Dep't v. Wright, 364 U.S. 642, 647.48 (1961).

12. United States v. Swift \& Co., 286 U.S. at 119.

13. United States v. Swift \& Co., 189 F. Supp. at 904; United States v. Besser Mfg. Co., 125 F. Supp. 710, 713 (E.D. Mich. 1954).

14. United States v. Swift \& Co., 189 F. Supp. at 906, 912.

15. United States v. Swift \& Co., 286 U.S. at 119.

16. See United States v. Swift \& Co., 189 F. Supp. at 912.

The rule for modification of decrees of continuing effect in the state courts is similar to Swift; a change in circumstances making the original decree unduly oppressive is a prerequisite for relief. See, e.g., Ozark Bi-Products, Inc. v. Bohannon, 224 Ark. 17, 21, 271 S.W.2d 354, 357 (1954); Sontag Chain Stores Co. v. Superior Ct., 18 Cal. 2d 92, 95, 118 P.2d 689, 690 (1941); Jackson Grain Co. v. Lee, 150 Fla. 232, 237-38, 7 So.2d 148, 146 (1942); Emergency Hosp. v. Stevens, 146 Md. 159, 166, 126 Atl. 101, 104 (1924); Weaver v. Mississippi \& Rum River Boom Co., 30 Minn. 477, 479, 16 N.W. 269, $269-70$ (1883); Board of 
The policies underlying the Swift rule are easy enough to ascertain. Re-examination of the original decree is thought to be an unproductive expenditure of the limited resources of the judiciary, largely involving a reassessment of matters supposedly considered by the entering court. ${ }^{17}$ Also, requests for modification place a considerable burden of defense upon the parties opposed to such modification. And, it must be remembered, the moving party has already had one chance to fashion an acceptable decree. Finally, in many instances, the opposing parties will have relied upon the terms of the original decree. ${ }^{18}$ To some extent, these are the same considerations that underlie the doctrine of res judicata. In fact, the Swift test may be viewed as a branch of that broader doctrine. Two important differences, however, should be kept in mind. Res judicata normally applies to separate and subsequent proceedings while the Swift test governs the reopening of a proceeding over which the court has continuing jurisdiction. And res judicata, when applicable, is usually considered an absolute prohibition against the reconsideration of issues previously adjudicated. ${ }^{10}$ In the case of a decree of continuing effect to which the Swift rule applies, the courts retain the inherent power to modify or vacate the decree at any time. ${ }^{20}$

Supposedly the Swift case established a comprehensive test covering all requests for modification by private parties and by the Government. ${ }^{21}$ When the request for modification is made by a private party

County Comm'rs v. Scott, 178 Neb. 53, 54-55, 131 N.W.2d 711, 712 (1964); Johnson \& Johnson v. Weissbard, 11 N.J. 552, 555-56, 95 A.2d 403, 405 (1953); People v. Sanlon, 11 N.Y.2d 459, 462, 184 N.E.2d 302, 303 (1962); 46 So. 52d St. Corp. v. Manlin, 404 Pa. 159, 160, 172 A.2d 154, 155 (1961); Ladner v. Siegal, 298 Pa. 487, 497, 148 Atl. 699, 702 (1930); Uvalde Paving Co. v. Kennedy, 22 S.TW.2d 1091, 1092 (Tex. 1929). A state court may grant modification more liberally when the decree limits the exercise of a right guarantced by the fourteenth amendment, such as union picketing. See Self v. Taylor, 217 Ark. 953, 964, 235 S.W.2d 45, 51 (1950). The federal courts make a similar exception in such cases. Sec Milk Wagon Drivers Union v. Meadowmoor Dairies, Inc, 312 U.S. 287, 293 (1941).

17. Cf. United States v. Swift \& Co., 286 U.S. at 119; 7 MOore, op. cit. supra note 9, at 288.

18. See James, Crvil Procedure § 11.1, at 517-18 (1965). The degree to which a private defendant can rely upon the consent decree would seem to be significantly related to the attractiveness of such a decree as an alternative to litigation. One advantage of the Swifl rule is that, where applicable, it makes the decree in question relatively permanent. But if this reliability is decreased, as by a more lenient test for modification when requested by the Government, it is not unreasonable to assume-as we in fact do-that in future cases defendants will be less willing to join the Government in a consent decree. This of course would reduce the efficacy of the Government's consent decree program.

19. Cromwell v. County of Sac, 94 U.S. 351, 352-53 (1876).

20. United States v. Swift \& Co., 286 U.S. at 114; JAMES, op. cit. supra notc 18, $\$ 11.8$.

21. The Supreme Court's decision in Swift

... has been cited as authoritative in more than one hundred subsequent decisions, 
the Swift rule is in fact almost universally applied.22 There is nothing in the Court's language in Swift to suggest that the Government stands on a different footing than a private party. But several Supreme Court cases cast some doubt upon the supposition that the Swift test is an accurate statement of present law with regard to Government motions for modification. ${ }^{23}$

The most recent of these cases is Columbia Artists Management, Inc. v. United States, ${ }^{24}$ which was decided in May of 1965. A consent decree had previously been entered against Columbia and another firm which managed professional concert artists and against two concert services affiliated with the two management firms. ${ }^{25}$ The decree

both in the lower courts and by the Supreme Court itself. Nothing has been decided since to cast doubt on its continued vitality or to limit its scope.

United States v. Swift \& Co., 189 F. Supp. 885, 901 (N.D. I1l. 1960). The Government has sought modification only infrequently. However, many commentators assume that it as well as private parties is bound by the Swift rule or by a similar strict hardship test. Goldberg, op. cit. supra note 2, at 6-7; Dabney, Antitrust Consent Decrees: How Protective an Umbrella, 68 YALE L.J. 1391, 1392-93 (1959); Jinkinson, Negotiation of Consent Decrecs, 9 Antrtrusr Bull. 673, 682 (1964); Kramer, Modification of Consent Decrees: A Proposal to the Antitrust Division, $56 \mathrm{MICF}$. L. REv. 1051, 1054-62 (1958); Comment, 55 Micil. L. REv. 92, 97 (1956); Comment, 32 Rocky Mr. L. REv. 367, 369-72 (1960); Note, 58 CAlip. L. REv. 627, 634 (1965). On the other hand, a few commentators have suggested that the test for the Government has been relaxed. REPORT 4; Duncan, Post-Litigation Resulting from Alleged Non-Compliance with Government Antitrust Consent Decrees, 8 W. REs. L. REv. 45, 48-49 (1956); Phillips, The Consent Decree in Antitrust Enforcement, 18 Wasil. \& LeE L. REv. 39, 45 (1961). The Swift test was specifically applied to the Government in United States v. Radio Corp. of America, 46 F. Supp. 654 (D. Del. 1942).

22. E.g., United States v. Northern Cal. Pharmaceutical Ass'n, 235 F. Supp. 878 (N.D. Cal. 1964) (consent decree); United States v. Lucky Lager Brewing Co., 1962 Trade Cas. 77,062 (D.C. Utah) (consent decree); United States v. Owens-Corning Fiberglas Corp., 178 F. Supp. 325 (N.D. Ohio 1959) (consent decree). United States v. International Boxing Club, Inc., 178 F. Supp. 469 (S.D.N.Y. 1959) (litigated decree); United States v. Besser Mfg. Co., 125 F. Supp. 710 (E.D. Mich. 1954) (litigated decree).

The application of the Swift test to litigated as well as consent decrees may be justificl on the grounds that, despite differences in their formulation, litigated and consent decrecs are of identical legal effect. See Isenbergh \& Rubin, Antitrust Enforcement through Consent Decrees, 53 Harv. L. REv. 386, 388 (1940). In Swift itself, Mr. Justice Cardozo statcd that the rule applied to both types of decrees. 286 U.S. at 114.

23. The following analysis is primarily focused upon the Government's cfforts to obtain modification of consent decrees. The Government has rarely sought modification of a litigated decree. See note 56 infra. Nevertheless, many of the same considerations apply to both litigated and consent decrees, and, to that extent, conclusions drawn in terms of the latter are generally applicable in the case of the former.

24. 381 U.S. 348 (1965).

25. United States v. Columbia Artists Management, Inc., 1955 Trade Cas. 70,380 (S.D.N.Y.).

The two original manager firms were Columbia Artists, Inc. and National Concert and Artists Corporation. After the original consent decree had been entered, Summy-Birchard, Inc. acquired and carried on the business of NCAC, but was subject to the terms of the 
allowed Columbia to use a standard contract which all concert services booking Columbia artists were required to sign.." Subsequently, the other management firm objected to Columbia that the contract permitted illegal resale price maintenance because it permitted Columbia to dictate both the artist's fee and the margin retained by the concert service. Fearing a suit by its competitor, Columbia petitioned the district court to approve its standard contract, arguing that the contract was specifically authorized by the consent decree.27 The district court refused to approve the contract, holding that "insofar as the decreeimposed requirement of margin operates to allow Columbia to set resale prices, the decree is illegal and void as contrary to the letter and policy of the Sherman Act." 28 At Columbia's request the district court permitted reargument on its "construction" of the decree. At the reargument the Government, which had previously argued that the

decree as a successor in interest. The concert services affiliated with Columbin Artists and Summy-Birchard were Community Concerts, Inc and Civic Concerts, Inc, respectively. Concert services organize local, non-profit audience associations, which are created and maintained by their members for the purpose of presenting annual concert series. Among its other functions, a concert service will book concert artists to perform at these loal concert series. The concert service collects the artist's fee from the audience association and then pays it to the artist's manager, deducting a percentage therefrom called the margin for its own services. Statement as to Jurisdiction for Appellant, pp. 2, 4, 5, Columbia Artists Management, Inc. v. United States, 381 U.S. 348 (1965).

26. The Standard Contract provided in part as follows:

It is agreed that this contract for the appearance of [name of Artist] is solely for the purposes of an engagement on the organized concert series in [town] for [dates] at the fee of $\$ \longrightarrow$ per engagement provided for in Columbia listings. . . . Brief for Appellant, pp. 3-4, Columbia Artists Management, Inc. v. United States, 381 U.S. 348 (1965).

27. Paragraph VI of the original consent decree provided:

Each defendant is enjoined and restrained from:

(A) Refusing to make available any artist managed by the defendant to any financially responsible audience association at the same fee charged by such artist to comparable audience associations where the artist is reasonably available for the desired performance. ...

(D) Refusing to making available to any financially responsible concert service any artist managed by such defendant and reasonably available for the desired performance, at the same margin allowed to the defendant or its afflinted concert services by that artist for a performance for the same fee. (Emphasis added.)

United States v. Columbia Artists Management, Inc, 1955 Trade Cas. 70,830, at 70,833 (S.D.N.Y.).

Columbia also contended that the offending provisions were required by a collective bargaining agreement between the manager firms and the concert artists' union. Bricf for Appellant, pp. 2-3, op. cit. supra note 26.

28. United States v. Columbia Artists Management, Inc, 1963 Trade Cas. 78,800, af'd on rehearing, 1964 Trade Cas. 79,265 (S.D.N.Y.). But see the dissent to the Supreme Court's decision suggesting that Columbia's standard contract may not in fact lave been unlawful. 381 U.S. at 352 . 
whole controversy surrounding Columbia's original petition was a sham, now asserted that the court's initial construction of the decree was correct. ${ }^{29}$ The district court reaffirmed its earlier decision. ${ }^{30}$

On appeal to the Supreme Court, Columbia argued that the district court had actually modified the decree by nullifying the clear meaning of one of its provisions. The Government argued for affirmance, contending that the district court had merely "construed" the decree..$^{31}$ In a one sentence per curiam opinion the Court affirmed the judgment below. ${ }^{32}$ Unfortunately, due to the brevity of the Court's opinion the grounds for the Columbia decision remain unclear. As the dissent filed by Mr. Justice Harlan, Mr. Justice Stewart and Mr. Justice Goldberg points out, the Government's contention that the lower court had merely construed the consent decree is unsound. ${ }^{33}$ Indeed, even the District Judge who declared Columbia's contract illegal recognized that the contract's terms were completely consistent with the original consent decree. ${ }^{34}$ Consequently, it is possible to interpret Columbia as allowing a modification of a consent decree without any showing of change of fact or law. ${ }^{35}$ If this interpretation is correct, the Columbia decision would support the proposition that when the Government urges the modification of a consent decree, the strict requirements of United States v. Swift \& Co. need not be met.

Several of the Court's pre-Columbia decisions may also be read to suggest that the Swift rule does not apply to motions made by the Government. The question was first raised in the so-called auto finance cases. $^{36}$ In 1938 the Chrysler Corporation and the Ford Motor Company had consented to decrees requiring them and their affiliated auto finance companies to separate and to cease certain discriminatory practices. These decrees were to lapse in 1941 if by then the Government

29. 1964 Trade Cas. at 79,266 (S.D.N.Y.). In the course of reargument the other manager firm abandoned its contention that Columbia's standard contract was unlawful, but the court found that the position taken by the Government preserved the adversary character of the proceedings. Ibid.

30. 1964 Trade Cas. 79,265 (S.D.N.Y.).

31. Brief for Appellant, pp. 7, 9, op. cit. supra note 26.

32. United States v. Columbia Artists Management, Inc., 381 U.S. 348 (1965).

33. Id. at 350-53. On other occasions the Supreme Court has refused to change a decrec under the guise of "interpreting" its terms. United States v. Atlantic Refining Co., 960 U.S. 19, 23-24 (1959); Hughes v. United States, 342 U.S. 351, 356-57 (1952).

34. " $[T]$ he decree clearly envisions that the artist or his manager will be able to control the ultimate price paid by the . . audience association." 1963 Trade Cas. 78,796, at 78,799 (S.D.N.Y.).

35. The dissenters gave the majority's decision this interpretation. 381 U.S. at 852 .

36. Chrysler Corp. v. United States, 316 U.S. 556 (1942); Ford Motor Co. v. United States, 335 U.S. 303 (1948). 
did not obtain a final judgment in an auto finance suit it was litigating against General Motors. ${ }^{37}$ By that date no conclusion to the General Motors suit was in sight. Nevertheless, both Ford and Chrysler agreed to an extension of the decrees. But when the Government requested a further extension in 1942, Chrysler objected. In Chrysler Corp. $v$. United States, the Supreme Court held that the extension granted by the district court over Chrysler's objections was proper:

We think the test to be applied in answering this question is whether the change served to effectuate or to thwart the basic purpose of the original consent decree. ${ }^{38}$

Although Swift was cited in support of this decision, the Court allowed a modification without any showing that there were sufficient changes to satisfy the Swift test. But in 1948, when Ford also objected to a further extension of the decrees, Mr. Justice Frankfurter, who had dissented in Chrysler, wrote the majority opinion in Ford Motor Co. v. United States, a 4-3 decision denying the United States' request. The majority held that the Government had not shown "good cause" why the court should release it from the terms of its own agreement. ${ }^{30}$

Though the Ford decision did not specifically relate its "good cause" criterion to the requirements of United States $v$. Swift ir Co., some commentators have analyzed the second auto finance case as a return to the strict test for modification. ${ }^{40}$ But Ford did not settle the issue. In 1959 a House Subcommittee on Antitrust reported that the test for modification, when urged by the Government, had been relaxed and was in fact the test used in Chrysler $v$. United States. $\$ 1$ This opinion, which was urged on the Subcommittee by the Justice Department,"2

37. The Chrysler and Ford consent decrees also provided for modification of their terms if the G.M. suit resulted in a less restrictive decree. 316 U.S. at 558; 335 U.S. at 307 n.1, 310-11.

Consent decrees sometimes include such provisions, which purport to allow modification or dissolution under different or less restrictive conditions than the courts are thought normally to require. For examples of such decrees, see 2 Trade REc. REP. I 8842 (1965); Dabney, supra note 21, at 1396 n.22. The Government does not appear to have benefited from this type of provision. United States v. International Harvester Co., 274 U.S. 693 (1927); Kramer, supra note 21, at 1061. But defendants have occasionally fared somewhat better. United States v. Twentieth Century Fox Film Corp., 1957 Trade Cas, 72,784 (1956); Allen Calculators, Inc. v. National Cash Register Co., 322 U.S. 137, 138-39 (1944); Ford Motor Co. v. United States, discussed in text accompanying note 39 infra.

38. 316 U.S. 556, 562 (1942).

39. 335 U.S. 303,322 (1948).

40. Comment, 32 Rocsy MT. L. Rev. 367, $371-72$ (1960); Comment, 55 Mirar. L. REv. 92,97 (1956).

41. REPORT 4.

42. Id. at 5 . 
rests upon an interpretation of two additional cases, Hughes $v$. United States $^{43}$ and Liquid Carbonic Corp. v. United States. 44 In both cases, district courts had, at the Government's request, granted substantial modification of consent decrees, and in both the Supreme Court reversed on procedural grounds. But in a dictum in the Hughes decision the Court indicated the conditions under which such modification would be proper. The Court did not specifically refer to either the Chrysler or the Ford decisions. But it suggested that modification of an antitrust consent decree is proper "where necessary to preserve competition and to prevent monopoly." 45 If meaningful at all, this dictum is more consistent with the liberal test enunciated in Chrysler than the rule of United States $v$. Swift \& Co. The Court later followed the Hughes decision in Liquid Carbonic. ${ }^{40}$

After the Hughes and Liquid Carbonic cases, the Supreme Court did not again consider the test for the Government until its ambiguous Columbia decision. Consequently, there is today no clear statement of what the applicable test is. The Supreme Court has never stated that the strict Swift rule does not apply to the Government. Nonetheless, at least four of the Court's five relevant decisions indicate, albeit in an ambiguous fashion, that Government motions for modification might be judged by a more lenient standard. At the very least, the ambiguity of the cases indicates an uneasiness on the part of the Court to apply a strict test to the Government.

In light of the general application of the Swift test to private party motions, a less strict test for the Government hardly seems to be even-handed justice. At first glance, it would seem that the policy considerations thought to underlie the Swift rule-such as the conservation of judicial resources-are equally applicable to government and private parties. It might be argued that, as a practical matter, the Government is less likely to make unwarranted or frivolous requests for modification. But even if correct, this argument is not the most satisfactory basis for distinguishing between private and government requests for modification. The question then arises whether there are in

43. 342 U.S. 353 (1952).

44. 350 U.S. 869 , affirming, 123 F. Supp. 653 (1954).

45. 342 U.S. at 357 .

46. 350 U.S. 869 (1954) (per curiam). The Justice Department clearly stretched a point in arguing before the House Subcommittee that Liquid Carbonic had established a relaxed test for the Government. The main holding of the Hughes decision was that substantial modification of a consent decree is improper without an adequate hearing on the merits. 342 U.S. at 357-58. It was for this rule, not the dictum concerning the standards for modlfication, that Hughes was followed in Liquid Carbonic. Cf. Dabncy, supra note 21, at 1894 n.I5. 
fact significant policy considerations which, though ignored under the Swift rule, might compel a more liberal modification test in certain situations.

The view that Swift applies to both the Government and to private parties rests in large part upon a contractual analysis of consent decrees. Although the commentators recognize that a consent decree is not a contract but a judicial act, the majority of the commentators nevertheless seem to place great emphasis upon the contractual underpinnings of the consent decree. ${ }^{47}$ Indeed, the terms of a consent decree are negotiated in private between the parties before being presented for court approval. ${ }^{48}$ Furthermore, in most cases, the courts play only a ceremonial role in the process, approving the terms of the decree as a matter of course.49 The view that a consent decree reflects the give and take of a bargaining process and is "in the nature of a solemn contract" upon which the parties have a right to rely"0 leads to the conclusion that the parties must be equally bound by its terms. Consequently, it is argued, both the Government and private defendants must satisfy the strict requirements of Swift before modification will be allowed. ${ }^{51}$

There are, however, important difficulties with over-emphasizing the contractual elements of consent decrees. Generally, the objective of consent decrees to which the Government is a party is to secure enforcement of federal law in an economic manner. The very authority of a court to enter the decree is supposedly dependent upon a determination by the court that the terms proposed by the parties are in the public interest.52 But does it make sense to bind the Government, and ultimately the public, to a continuing decree which may no longer be (or may never have been, for that matter) in the public interest? This is precisely what may happen under a rigid contractual approach, for

47. E.g., GoldBERG, op. cit. supra note 2, at 19; Kramer, supra note 21, at 1058.

48. Phillips, supra note 21 , at 40 .

49. GOLDBERG, op. cit. supra note 2, at 20-21; REPORT 14; Jinkinson, supra note 21, at 676 .

50. United States v. Hartford-Empire Co., I F.R.D. 424,426 (N.D. Ohio 1940) [quoting 12 C.J. Consent Decree (1917)].

51. See Comment, 55 Mrcr. L. Rev. 92, 95-96 (1956); Peterson, Consent Decrees: A Weapon of Anti-trust Enforcement, 18 U. KAN. CrTY L. REv. 34, 40 (1950), for a discussion of this view. As noted earlier, supra note 3 , the Justice Department secks to include in antitrust consent decrees more extensive relief than a court could properly grant in a similar litigated case. Supposedly, only a contractual approach could justify such provisions; since a court under the antitrust laws could not impose them upon the defendant, they are only enforceable if the defendant binds himself. Cf. Comment, supra, at 95.

52. United States v. Radio Corp. of America, 46 F. Supp. 654, 655 (D. Del. 1942); Oppenheim, supra note 3, at 1233. 
the consent decree-which finds its main justification in its service to the public interest (by securing adherence to federal laws at minimum cost)-may be turned into an inflexible device whereby the Government is bound permanently to an agreement which is actually detrimental to the public interest. This point is amply illustrated by the Columbia litigation. Had the Court not allowed modification, a flawed but iron-bound consent decree would have permitted Columbia to dictate artists' resale prices.

Another objection to the contractual approach is that it emphasizes and legitimates a practice which undermines the court's responsibilities in formulating and entering consent decrees. Theoretically, before entering a consent decree the court should scrutinize the terms of the agreement. For example, in the case of an antitrust consent decree, a court should "satisfy... [itself] that the agreement does justice between the industry and the public." 33 But, as noted earlier, the courts rarely carry out their responsibility. In the overwhelming majority of cases, courts leave the entire process to the Government and enter consent decrees as a matter of course, without making an independent determination of the decree's merit. ${ }^{54}$

At this point, the pernicious consequences of applying the Swift test to the Government should become apparent. If it were true that courts adequately examine consent decrees before entering them, then the Swift rule might not be unreasonable. Unless conditions have changed unforeseeably, Swift would prevent a second court from re-examining a matter actually considered by the entering court (although the argument that the public should not be bound by a bad decree might still apply). But since courts generally play only a formal role in entering consent decrees, the strict application of the Swift test to the Government may create a situation whereby the public will be bound to a faulty or inadequate consent decree which has never been subjected to independent judicial scrutiny.

In a utopian world with unlimited judicial resources the ideal solution might be to insist that courts entering consent decrees actually fulfill their theoretical responsibilities. However, such a solution is unrealistic. The perfunctory manner with which courts enter consent

53. hamilton \& Till, ANTrtrust in Action 88 (TNEC Monograph No. 16, 1911).

54. On rare occasion, the courts have played an active role in consent decree procced. ings. Thus, in two cases, courts entered consent decrees without the Government's conscht, United States v. Brunswick-Balke-Collender Co., 203 F. Supp. 657 (E.D. Wisc. 1962); United States v. Aero Mayflower Transit Co., 1956 Trade Cas. 72,140 (S.D. Ga.). And in another, a court refused to enter a consent decree and ordered the parties to go to trial, United States v. Pan American World Airways, Inc., 1959 Trade Cas. 75,188 (S.D.N.Y.). 
decrees is largely dictated by the pressure of crowded dockets and by the lack of an adversary presentation of the decree's merits and defects. ${ }^{55}$ In addition, the very raison d'être of the consent decree lies in its utility in concluding disputes in a quick and economic manner. Clearly, any requirement that courts undertake a thorough examination of consent decrees at the point of entrance would greatly diminish the practical value of such decrees.

Instead of making unrealistic demands upon the courts, a better solution is to recognize existing conditions. Rather than insist that courts examine thoroughly every consent decree presented for approval, we should permit them to continue to rely upon the Government's judgment when entering such decrees. But if the Government later requests modification on the grounds that the decree does not operate in the public interest, then a court should not be barred from considering the merits of the Government's request and granting modification in appropriate cases. Not only is this the point when judicial attention is most needed, it is also the point when judicial supervision can be most effective, for the court will be able to exercise a more informed judgment than at the time the decree was entered. The court need not guess at the effect the terms of the decree will have. The effect will be a matter of record.

The foregoing analysis indicates that modification requests made by the Government should be judged by a more lenient test than the Swift rule. ${ }^{50}$ This is because the Swift test is unresponsive to a number of

55. See GolDBERG, op. cit. supra note 2, at 20-21; HAxiLton \& TiLl, op. cit. supra note 53 , at 88 .

56. The few cases in point suggest that a more lenient test than Swifl has been applied when the Government requests modification of litigated decrees. In one case a district court modified the terms of a litigated decree, stating that "the determinative test is whether such modification is reasonably necessary to effectuate the basic purposes of the decree," United States v. United States Gypsum Co., 124 F. Supp. 573,590 (D.D.C. 1954)-an apparendy lib. eral test which virtually paraphrases the rule enunciated by the Supreme Court in Chrisler Corp. v. United States. See text accompanying note 38 supra. On appeal, however, the Su. preme Court held that some of the relief granted by the district court in the Gypsum ase was improper because it enlarged the scope of the decree bejond that of the issues adjudi. cated. United States Gypsum Co. v. National Gypsum Co., 352 U.S. 457, 465 (1957). But the Court approved the relief granted below which it felt more effectively enforced the terros of the original decree. 352 U.S. at 464 . Other cases in which courts appear to have considered modification requests in terms of the basic purpose test are United States v. Watchmakers of Switzerland Information Center, Inc, 5 Trade REc. REp. (1965 Trade Cas.) I 71,352, at 80,490 (S.D.N.Y. 1965) (modification requested by Government and defendant): United States v. Imperial Chemical Industries, Ltd., 1957 Trade Cas. 73,474 (S.D.N.Y.) (Government's motion for modification denied).

The basic purpose approach seems to be reasonable. Admittedly, one of the arguments advanced in support of a permissive test for modification of consent decrees-the fact that 
important considerations which should affect a determination whether modification, in a given case, is in the public interest. Foremost among these is a concern with securing adequate enforcement of law. There are other interests, too, which might indicate the necessity of modifica. tion. For example, dissolution of injunctions against public officials should be (and in fact is) granted as soon as the Government can show that the need for the decree no longer exists. ${ }^{67}$ This result, although it may be permissible under a flexible reading of the Swift rule, is properly attributable to the courts' sensitivity to the important public interest in the unhampered operation of governmental units. ${ }^{68}$ What is proposed, in short, is a test for modification requests which balances the governmental interests favoring modification against the factors underlying the Swift rule which militate against modification. ${ }^{50}$ As

courts enter such decrees in a perfunctory manner-is absent in the case of litigated decrees. Thus, in the absence of a wholly unforeseeable change in conditions (the first requirement of Swift), modification of a litigated decree will entail some re-cxamination of issues previously considered by the entering court. But, on the other hand, it must be remembered that a court has continuing supervisory jurisdiction over the operation of an injunctive decree. United States v. Swift \& Co., 286 U.S. at 114; JAMEs, op. cit. suppra note 18, at 548. Furthermore, the public's interest in adequate enforcement of the law is just as compelling a consideration with respect to litigated as to consent decrees. In cither casc, should the advantage of hindsight prove modification to be desirable, it makes little sense to remain imprisoned within the confines of the original decree.

57. Hodges v. Snyder, 261 U.S. 600, 602 (1923); see Dombrowski v. Pfister, 85 S. Ct. 1116, 1124 (1965).

58. Cf. Katzenbach v. McClung, 85 S. Ct. 6, 7 (1965); Township of Hillsborough v. Cromwell, 326 U.S. 620, 622 (1946); Hurley v. Kincaid, 285 U.S. 95, 104 n.3 (1932); Mathews v. Rodgers, 284 U.S. 521, 525-26 (1932); Porto Rico Tel. Co. v. Puerto Rico Communications Authority, 189 F.2d 39, 41 (C.A. Puerto Rico 1951); Rhodes v. Houston, 202 F. Supp. 624. 639 (D.C. Neb. 1962).

59. To be consistent, a similar balancing procedure should be followed in judging modlfication requests made by private parties. Essentially, the question before the court would be whether the factors which militate against modification are outweighed by some public interest which modification would serve. Excepting cases in which the exercise of first or fourteenth amendment rights is restricted, see note 16 supra, a private party will only rarcly be able to demonstrate that a public interest will be significantly enhanced by allowing modification. But see American Press Ass'n v. United States, 245 Fed. 91, 93 (7th Cir. 1917). Usually, such a party will only be able to argue that removal of the restrictions of the original decree will allow it to operate more efficiently and perhaps more profitably. Admittedly, increased efficiencies in the private sector of the economy are in the public interest. But the important point is that such benefits are unlikely to outwcigh the adverse effects of permitting modification in such cases.

But see United States v. Little Rock Packing Co., 202 F.2d 234 (8th Cir. 1953); Tobin v. Alma Mills, 192 F.2d 133 (4th Cir. 1951). In these cases the Fourth and Eighth Gircuits have taken the position that mere good faith compliance with the terms of a Fair Labor Standards Act injunction provides sufficient grounds for its dissolution. Tobin v. Alma Mills, supra, at 136. But other courts have specifically rejected this rule and adhered to the test of United States v. Swift. Wirtz v. Graham Transfer \& Storage Co., 322 F.2d 650, 651 (5th Cir. 1963); Goldberg v. Ross, 300 F.2d 151 (1st Gir. 1962); Walling v. Harnischfeger Corp., 242 F.2d 712 (7th Cir. 1957). 
noted earlier, these latter factors include the burden re-examination places upon courts, the importance to prosecutors desirous of obtaining consent decrees of maintaining the expectation that such decrees will be reasonably stable, and considerations of fairness to private parties who may have relied on a decree. ${ }^{00}$

Although we accept the basic validity of the concerns underlying Swift we do not think the court should accept them without inquiry in each case. For example, under Swift the private party's reliance interest was considered in gross. Whenever there was a decree the private party opposed to modification was assumed to have some kind of reliance

The Fourth and Eighth Circuits follow the good faith rule because they believe that FLSA injunctions work a hardship upon the enjoined employer, compare Mitchell $v$. Helena Wholesale, Inc., 163 F. Supp. 101, 105 (E.D. Ark. 1958), wilh Wirtz v. Graham Transport \& Storage Co., supra, at 653, and because they feel that government by injunction is an undesirable form of social regulation. Tobin v. Alma Mills, supra at 136. However, these reasons do not justify a deviation from Swift. FLSA injunctions are issued only after the court has decided that a permanent restraint is necessary to prevent further violations, $c f$. , Walling v. Youngerman Reynolds Hardwood Co., 325 U.S. 419, 421 (1945), or after the defendant has voluntarily bound himself. Furthermore, the government by injunction to which the "good faith" courts object was specifically authorized by Congress. Fair Labor Standards Act $\S 17,52$ Stat. 1069 (1938), 29 U.S.C. $\S 217$ (1964). Finally, under the lenient good faith compliance test, defendants would be encouraged to make repeated motions to vacate outstanding injunctions, thereby increasing the burden of pending litigation upon the courts. For an example of the potential for abuse in the good faith rule, see Goldberg v. Ross, supra.

60. Of course, one may argue that the Government's interest in modification should be the only relevant interest to be considered by the court. Reliance by the private parties, although an interest of some emotional appeal, is not one we usually allow to thwart law enforcement. For example, when laws change, we usually do not listen to parties who claim exemption based on reliance interests in the old law. Sce, e.g., Wisconsin \& Mfich. Ry. Co. v. Powers, 191 U.S. 379 (1903). Neither, it can be argued, should we allow reliance to thwart enforcement of a consent decree, especially since it is often doubtful that the private party has sacrificed very much by consenting. This is particularly true in the case of antitrust consent decrees to which defendants agree largely to avoid treble damage suits which might arise if the Government successfully proved a violation of the antitrust laws. To this extent, the argument of an antitrust defendant that he agreed to a consent decree in order to obtain its specific terms and that any modification would constitute a substantial injury is, of course, weakened.

On the other hand, a one-sided approach considering only the Government's enforcemental interests is necessarily totally unresponsive to any of the considerations underlying Swift, considerations which are of considerable merit. Such an approach would also tend to destroy the utility of the consent decree device. Defendants would quidily find that they had thrown themselves at the mercy of the Government, and whatever advantages they had previously derived from consent decrees would pale by comparison. Furthermore, even if one chooses to ignore all the practical advantages to defendants, to the Government and to the courts which would be displaced by an exclusively enforcemental approach, there is one further objection: consent decrees are instruments of the court, specifically a court acting in equity. For such a court to ignore totally the interests and concerns of a private defendant in favor of the Government would be wholly inconsistent with the spirit of the principles upon which its authority is founded. 
interest. Our approach insists on a more discriminating inquiry. In each case the court should determine how much the party would be injured by the requested change, whether the change would injure the party because he had been acting in reliance upon the decree or, instead, because he had been acting totally independent of the decree, and finally how legitimate the reliance was. As an illustration, suppose a corporation is explicitly enjoined from following certain trade practices. No mention is made of allowable practices. When the number of competitors within the industry drops off the Government seeks a modified decree that will enlarge the list of forbidden practices. In this case a reliance interest should not be found unless the private party can show that ( 1 ) he had invested a substantial amount of money in one of the new prohibited practices which would be lost because of the change, (2) his investment was induced by the consent decree and would not have been made without the decree, and (3) his reliance was reasonable. ${ }^{61}$ In this case the party might not be able to make the requisite showing. A change in a particular trade practice might not necessarily cause a loss in a previous investment. The company prob. ably would have instituted or continued the trade practice without the decree. And it is probable that nothing in the decree or the Government's action reasonably could have induced the private party to rely on the legality of the practice. Suppose instead that the consent decree specifically allowed a parent corporation to retain control of its subsidiary. ${ }^{62}$ After a similar change in the competitive structure of the industry the Government requests divestiture. In this case the corporation might be able to show a reliance interest more readily if, for example, it had invested in the subsidiary, if the subsidiary had grown and if, consequently, divestiture was more expensive. Here the injury is real and is induced by a reasonable reliance on the decree. These two examples merely illustrate some of the various kinds of factors relevant to a determination of reliance. Our aim is only to suggest that if reliance is to be balanced against the Government's interest in modification, reliance should not be taken for granted. A real inquiry should be made. ${ }^{63}$

61. For an analogous approach to reliance on a promise, sec $1 \mathrm{~A}$ Condin, Contracrs $\S 205$ (1963).

62. The Government agreed to such a decree in United States v. Western Electric Co., 1956 Trade Cas. 71,135 (D.N.J.), and was subsequently heavily criticized for its decision. See REPORT 290-94.

63. Of course, modification is never proper without an adequate hearing. Hughes $v$, United States, 342 U.S. 353, 357-58 (1952). Such a hearing requires the introduction of evidence and judicially determined findings of fact. Ibid. In the course of such a hearing the court should permit the parties to raise all the issues relevant to the modification 
Admittedly, the balancing approach suggested will permit modification somewhat more readily than the Swift test. ${ }^{04}$ (Although it should be realized that, if past experience is any guide, modification is only requested by the Government in a relatively small percentage of cases.) But, at the same time, the suggested approach will eliminate one practice under the Swift test which may seriously undermine the rights of those who oppose modification. ${ }^{05}$ The elimination of the rigid Swift requirements will enable courts to modify unacceptable decrees without resorting to the fiction that they are merely "construing" the original decree. The law is clear that modification is improper without a hearing on the merits. But if modification is disguised as construction (as the dissenters convincingly argued occurred in the Columbia litigation), no such hearing is available, for the court's inquiry is limited to the four corners of the decree in question. Freeing the courts from the rigidity of the Swift rule frees them from using the fiction of construction and insures those opposed to modification a hearing on the real issues at stake.

requested. For example, an opponent to modification may wish to show that provisions in the decree which at first glance seem unrelated to or unchanged by the proposed modifica. tion will be significantly affected. Such hidden connections between apparently unrelated aspects of a consent decree often arise as a result of the bangaining process by which such decrees are formulated. A provision assented to by one party may have represented the quid pro quo for a seemingly unrelated concession made by the other party. $\mathrm{In}_{1}$ such a case, a court might well permit the party opposing modification a hearing on such ques. tions as whether the intent of the whole decree might fail without the term in question or whether a specific term, though objectionable if considered alone, might be entirely permissible when considered as part of the decree as a whole.

64. As noted above (see text accompanying notes $32-36$ supra) it would be most difficult to reconcile the Columbia decision with the Swift test. But Columbia is completely consistent with the balancing approach. Although there had been no change in conditions since the decree was entered, modification was justified because the decree permitted unlawful behavior. Similarly, under a balancing approach the Government might legitimately obtain modification when there had been no change whatsoever except in Administration atitude regarding antitrust policy-provided, of course, that the court is convinced, after considering all the relevant factors, that the requested modification is in fact justified in the public interest.

65. It may be argued that the suggested approach actually represents a clarificationas opposed to an extension-of existing law. Columbia and the earlier Supreme Court decisions which considered governmental requests for modification certainly reflect-but in an unarticulated manner-the Court's solicitude for significant public interests. Two ancillary advantages will result from a clear articulation of the balancing test for the Government: First, the dominant importance of the public interest will be definitely established, disabusing courts and commentators alike of the 'contractual' notion of the consent decree. Cf. United States v. Carter Products, 211 F. Supp. 144, 147-48 (S.D.N.Y. 1962). Second, a clear statement of the conditions under which the Government may obtain modification will enable privàte parties contemplating such a decree to analyze more effectively the precise risks and disadvantages which the consent decreep.involves. It will introduce a note of certainty where confusion now exists. 